\section{European Space Agency (ESA)}

History. Established in 1975, replacing the European Space Research Organization (ESRO) and the European Launcher Development Organization (ELDO).

Members. Austria, Belgium, Czech Republic, Denmark, Estonia, Finland, France, Germany, Greece, Hungary, Ireland, Italy, Luxembourg, the Netherlands, Norway, Poland, Portugal, Romania, Spain, Sweden, Switzerland, United Kingdom. Canada takes part in some projects under a co-operation agreement.

Activities. ESA is the intergovernmental agency in Europe responsible for the exploitation of space science, research and technology for exclusively peaceful purposes. Its aim is to define and put into effect a long-term European space policy that allows Europe to remain competitive in the field of space technology. It has a policy of co-operation with various partners on the basis that pooling resources and sharing work will boost the effectiveness of its programmes. Its space plan covers the fields of science, Earth observation, telecommunications, navigation, space segment technologies, ground infrastructures, space transport systems and microgravity research.

Headquarters: 8-10 rue Mario Nikis, 75738 Paris Cedex 15,

France.

Website: http://www.esa.int

Director-General: Johann-Dietrich Woerner (Germany).

\section{CERN - The European Organization for Nuclear Research}

Founded in 1954, CERN is the world's leading particle physics research centre. By studying the behaviour of nature's fundamental particles, CERN aims to find out what our Universe is made of and how it works. CERN's biggest accelerator, the Large Hadron Collider (LHC), became operational in Sept. 2008. One of the beneficial byproducts of CERN activity is the Worldwide Web, developed at CERN to give particle physicists easy access to shared data. One of Europe's first joint ventures, CERN now has a membership of 21 member states: Austria, Belgium, Bulgaria, Czech Republic, Denmark, Finland, France, Germany, Greece, Hungary, Israel, Italy, the Netherlands, Norway, Poland, Portugal, Slovak Republic, Spain, Sweden, Switzerland, United Kingdom. Some 6,500 scientists, half of the world's particle physicists, use CERN's facilities. They represent 500 institutions and 85 nationalities.

Address: CH-1211 Geneva 23, Switzerland.

Website: http://home.cern

Director-General: Fabiola Gianotti (Italy).

\section{Central European Initiative (CEI)}

In Nov. 1989 Austria, Hungary, Italy and the then Yugoslavia met on Italy's initiative to form an economic and political co-operation group in the region.

Members. Albania, Austria, Belarus, Bosnia and Herzegovina, Bulgaria, Croatia, Czech Republic, Hungary, Italy, Macedonia, Moldova, Montenegro, Poland, Romania, Serbia, Slovakia, Slovenia, Ukraine.
Address: Executive Secretariat, Via Genova 9, 34132 Trieste, Italy. Website: http://www.cei.int

Email: cei@cei.int

Secretary General: Giovanni Caracciolo di Vietri (Italy).

\section{Nordic Council}

Founded in 1952 as a co-operative link between the parliaments and governments of the Nordic states. The co-operation focuses on Intra-Nordic co-operation, co-operation with Europe/EU/EEA and co-operation with the adjacent areas. The Council consists of 87 elected MPs and the committees meet several times a year, as required. Every year the Nordic Council grants prizes for literature, music, nature and environment.

Members. Denmark (including the Faroe Islands and Greenland), Finland (including Åland), Iceland, Norway, Sweden.

Address: Ved Stranden 18, DK-1061 Copenhagen K, Denmark.

Website: http://www.norden.org

Email: nordisk-rad@norden.org

President: Henrik Dam Kristensen (Denmark).

\section{Nordic Development Fund (NDF)}

NDF is a multilateral development finance institution established by the five Nordic countries, Denmark, Finland, Iceland, Norway and Sweden. Since operations started in 1989, the Fund has provided soft loans to 190 projects of Nordic interest in developing countries. It entered a new phase in 2009 and changed its focus to grant aid for climate change-related projects.

Address: Fabianinkatu 34, PO Box 185, FI-00171 Helsinki, Finland.

Website: http://www.ndf.fi

Email: info.ndf@ndf.fi

Managing Director: Pasi Hellman (Finland).

\section{Nordic Investment Bank (NIB)}

The Nordic Investment Bank, which commenced operations in 1976, is a multilateral financial institution owned by Denmark, Estonia, Finland, Iceland, Latvia, Lithuania, Norway and Sweden. It finances public and private projects both within and outside the Nordic area. Priority is given to projects furthering economic co-operation between the member countries or improving the environment. Focal points include the neighbouring areas of the member countries.

Address: Fabianinkatu 34, PO Box 249, FI-00171 Helsinki, Finland. Website: http://www.nib.int

Email: info@nib.int

President: Henrik Normann (Denmark).

\section{Council of the Baltic Sea States}

Established in 1992 in Copenhagen following a conference of ministers of foreign affairs. 